\title{
Impact of Milky Mushroom Cultivation and Value Addition Trainings among the Unemployed Youth of Ballari District, India
}

\author{
Shilpa Huchchannanavar ${ }^{1 *}$, G. Ravishankar ${ }^{1}$ and V. Anandkumar ${ }^{2}$ \\ ${ }^{1}$ ICAR-KrishiVigyan Kendra, Hagari, Ballari District, Karnataka, India \\ ${ }^{2}$ Agricultural Entomology, University of Agricultural Sciences, Raichur, India \\ *Corresponding author
}

\begin{tabular}{|c|}
\hline Keywords \\
\hline $\begin{array}{l}\text { Milky mushroom } \\
\text { cultivation, Value } \\
\text { Addition, } \\
\text { Unemployed Youth }\end{array}$ \\
\hline Article Info \\
\hline $\begin{array}{l}\text { Accepted: } \\
\text { 15 December } 2019 \\
\text { Available Online: } \\
20 \text { January } 2020\end{array}$ \\
\hline
\end{tabular}

\section{A B S T R A C T}

Mushrooms, also called as 'white vegetables' or 'boneless vegetarian meat' contain ample amount of proteins (20-35\%), vitamins and fibre. Milky mushroom is robust, fleshy, milky white, umbrella like mushroom, having long shelf-life and lucrative market value. Ballari District lies in Northern dry zone of Karnataka receive $28-29^{\circ} \mathrm{C}$ mean temperature in January and highest maximum temperature in May reaches $43^{\circ} \mathrm{C}$. Hence, different mushroom species can be cultivated due to prevailing wide range of temperature in the District. Paddy/rice is the major crop grown in Ballari district $(75,000 \mathrm{Ha})$ under Tungabhadra irrigation command area and plenty of paddy straw is available to grow mushrooms which is either wasted or burnt by the farmers. Realising the scope for tropical mushrooms like oyster (Pleurotus spp.) and milky mushroom (Calocybeindica) in the District, trainings have been given to the interested farmers, farm women and rural youths at ICARKrishi Vigyan Kendra, Hagari, which in turn increased their knowledge level and has created a favourable attitude. A complete list of 250 respondents was randomly prepared who have undergone through training and demonstration on mushroom production technique from 2016 to 2019. It was observed that pretraining knowledge score was not much satisfactory, however, the knowledge score gained after training was more satisfactory in all the aspects. The exposure to training had increased the knowledge of trainees regarding techniques of mushroom production. The reason behind the satisfactory change in perception level might be due to keen interest of participants and methods followed for technology transfer to the trainees. Some trainees adopted mushroom cultivation as self-employment and set up their own units. Few mushroom entrepreneurs have also extended their mushroom production to Value added products like mushroom pickles and dehydrated mushrooms. The study revealed that the mushroom production training has created a favourable attitude among the trainees and also enhanced the economic level of beneficiaries who adopted it as a source of livelihood. 


\section{Introduction}

The demand for mushroom is growing, because the nutritive value of mushroom has been rediscovered and recognized as a richer source of protein (Arti and Chauhan, 2014). Mushroom production has tremendous scope in Karnataka, however, the state does not have number of entrepreneurs to meet its requirements.

Indian agriculture will continue to be a main strength of Indian economy. With the variety of agricultural crops grown today, we have achieved food security by producing over 200 million tonnes of food grain. However, our struggle to achieve nutritional security is still on. Though we have significant achievements in milk, vegetables and fruit production still we have to do more. In future, the everincreasing population, depleting agricultural land, changes in environment, water shortage and need for quality food products at competitive rates are going to be important issues.

Mushroom farming today is being practiced in more than 100 countries and its production is increasing at an annual rate of $6-7 \%$. In some developed countries of Europe and America, mushroom farming has attained the status of a high-tech industry with very high levels of mechanization and automation. Present world production of mushrooms is around 3.5 million tonnes as per FAO Stat and is over 25 million tons (estimated) as per claims of Chinese Association of Edible Fungi.

Mushroom is a palatable food accepted by people as daily diet and alternative to meat and fish. Also it is a vegetarian diet but gives nutrition of non-veg such as some essential amino acids, vitamins and minerals. Straw, the main raw materials is plentily available. There is no constraint to get spawn, as many spawn units are there in the State. Now a day's people are fond of consuming mushroom in different ways like curry, snacks, soup, salad, mixed with rice, \& pickle etc. Technology is simple with low cost \& easily available to the interested entrepreneur. It is a quick returning crop with 50 to $100 \%$ profit for which financial support from any financial agencies are easy to get. Thus mushroom cultivation is another source for self-employment of unemployed school and college drop outs. To meet these challenges and to provide food and nutritional security to our people, it is important to diversify the agricultural activities in areas like horticulture and especially in mushroom cultivation.

The food consumption pattern in Karnataka is predominantly cereals and millets based with lesser amount of protective foods. Growth retardation has been observed in a vast majority of children in the country including Karnataka (Bhavani et al., 2008; Kesavan, 2015; Naveena et al., 2016). Protein energy malnutrition, vitamin A deficiency and Bcomplex deficiencies are the major nutritional deficiencies among pre-school children, while anaemia remains a major health problem in women (Sheela, 1999). WHO estimated that malnourished children numbered 181.9 million (32\%) in developing countries (ICDS, 1983). Protein energy malnutrition (PEM) is a potentially fatal body depletion disorder. In India, the proportion of children with PEM was $46 \%$ in 2005-2006 and in Karnataka it is 41 per cent (NFHS-3). However, the potential of mushroom to ameliorate this malady has not received commensurate attention it merits. Further, mushroom cultivation as an agribusiness creates lot of employment and income generation opportunities especially for weaker sections of the society (Singh et al., 2015).

Mushroom being one of the cheapest sources of protein particularly for the vegetarian, it 
becomes imperative to produce more mushroom utilizing the local agro-waste to meet the protein need of the country. Out of different mushrooms that can be cultivated on lignin rich agricultural wastes, milky mushroom (Calocybe indica) is relatively new to the world of mushroom industry. It grows well at room temperature between $25^{\circ} \mathrm{C}-$ $35^{\circ} \mathrm{C}$ and can be cultivated even on unfermented materials. The advantages of this mushroom over other mushrooms are easy method of cultivation, less investment, very attractive fruiting body, pleasing milk white color, long shelf life, more nutritious and less time to grow. In general, mushroom cultivation is practiced using traditional raw materials whose availability often become limiting. In rural areas, plenty of agro-waste and organic materials are available, which often end up in waste thus contributing to the pollution woes. Recycling is the need of modern times and mushroom is an ideal candidate to harness its potentialities.

Ballari District being in Northern dry zone of Karnataka receives $28-29 \circ \mathrm{C}$ mean temperature in January and the highest maximum temperature in May reaches $43^{\circ} \mathrm{C}$. A wide range of temperature prevails in this zone. Hence, a wide range of mushroom species can be cultivated in the zone. Below two are the important mushrooms suitable for cultivation in the zone: 1. Oyster mushroom (Pleurotus sajor-caju) 2. Milky mushroom (Calocybe indica). Ballari district is also known for its rice production, so plenty of paddy straw is available to grow mushrooms which is either wasted or burnt by the farmers. With this background ICAR-KVK, Hagari, trained the unemployed youth in setting their mushroom enterprises.

\section{Materials and Methods}

The training programs on mushroom production focused on unemployed youths and Self-help group women, those who have interest in self-employment. The study was conducted at ICAR-Krishi Vigyan Kendra, Ballari, Karnataka. A total of 250 respondents were selected randomly for training, out of 250 respondents 195 were men and 55 were women. Thorough training on various aspects of mushroom production was given which included the cultivation techniques through hands on experiences, substrates preparation, marketing of fresh product, value addition, exposure visit, demonstration units, cost benefit ratio, etc.

A questionnaire was framed covering background information. In order to assess the knowledge gained by the trainees and effectiveness of training, a pre-test before training and post evaluation after training was conducted to know the level of knowledge of participants about species, pest and disease infestation in mushrooms as well as their storage process and value addition etc.

Change of knowledge was tested through the formula given below (Shahi et al., 2018),

Deviation/change of Knowledge $=$

After training - Before training X 100

Total respondents

\section{Results and Discussion}

Trainings helps farmers to incorporate the latest scientific advances and technology tools into their daily operations or sometimes totally new things will be learnt from the trainings. Milky mushrooms have been introduced to Ballari District which was not known enterprise to the whole area. Nearly ten on campus and off campus trainings on mushroom cultivation were given to the SHG and unemployed youth of the District. Knowledge on importance of mushroom consumption and production was also 
telecasted and broadcasted on DD Chandana TV and All India Radio, Hospet. The success stories were also published in newspaper dailies and University magazines.

Training courses aim at enhancing adoption and diffusion of innovations. Some of the outcomes envisaged for any training programme were gain in knowledge, gain in skill acquired and ultimately in more adoption and integration among farming community. An important indicator of the impact of training programme is the extent, to which they have adopted the package of practice of mushroom cultivation technology (Veena et al., 2018).

Change in perception level of respondents before and after training was shown in Table 1.The positive attitude was developed for mushroom cultivation among the trainees after the trainings. The questionnaire was developed to understand their pre and post knowledge level during the trainings. In pretest knowledge of the respondents about the species was very less ie.,6 per cent of the respondents knew about mushroom species and 5.6per cent of them had the knowledge on the nutritional and medicinal properties. Around 3.6 per cent of the respondents knew the techniques and materials to grow mushrooms where as a very less percentage of trainees had knowledge on pest and diseases however around 21.6per cent of the respondents were aware of the profitability of the mushroom cultivation. Regarding harvesting, storage practices as well as value addition techniques were known to only 6per cent and 3.6per cent of the respondents respectively. About 1.6 per cent respondents knew about the loans, subsidies and facilities available for mushroom cultivation by government and private sectors.

The post-test knowledge of respondents was tested using the same questionnaire. The results of post knowledge scores increased significantly over the pre test scores. It was thus noticed that pre-training knowledge score was not much satisfactory for all the aspects of training programme. However, the knowledge score gained by respondents after training was more satisfactory in all the aspects. The reason behind the satisfactory change in perception level might be due to keen interest of participants and methods followed for technology transfer to the trainees.

Unemployed and well educated youth are showing lot of interest for mushroom cultivation. Youth from Guggarahatti, Vaddatti, Karekal and Kanekal, Kurgodu, Koulbajar, Siruguppa, Hospet, Sindhigeri and parts of Ballari city are actively involved in milky mushroom cultivation. Out of 250 trainees only 26 farmers started growing the mushrooms by setting up their own cultivation unit, whereas around eight farmers dropped the cultivation of milky mushrooms. When the reasons for dropouts analysed we found that losses occurred to these growers due to improper sterilization techniques, infections and contaminations, unable to give proper temperature and humidity to the mushroom bags, marketing constraints and problem of pseudo mushrooms occurred due to use of rain exposed paddy straw, lack of skilled labour, lack of transport, lack of storage facility etc. Michael et al., (2008) mentioned the time lag to obtain a return on investment, lack of funds, insufficient production and marketing information as the major constraints in mushroom production in US. Singh and Suresh (2007) concluded in their study that, lack of availability of quality spawn and high price of spawn along with pest and disease infection were major problems in mushroom production.

Since the demand and knowledge on mushroom consumption of the local people 
was less in the initial days it was a real threat for the interested mushroom farmers to sell their produce. Gradually few young growers found out the online marketing and wholesale marketing strategies to sell their produce. Now the mushrooms of Ballari are reaching Hyderabad and Kerala with the continuous efforts of these young growers.
Value addition and processing are the key elements in sustaining mushroom production. Two growers are also involved in making the value added mushroom products such as dehydrated mushrooms and mushroom pickles (Fig. 1) which were standardized by ICAR-KVK, Hagari.

Table.1 Change in perception level of respondents for mushroom production $(\mathrm{N}=250)$

\begin{tabular}{|c|c|c|c|c|c|c|}
\hline $\begin{array}{l}\text { S. } \\
\text { No. }\end{array}$ & Particulars & $\begin{array}{c}\text { Pre-test } \\
\text { Knowledge } \\
\text { before } \\
\text { training } \\
\text { (respondents } \\
\text { in Number ) }\end{array}$ & $\begin{array}{l}\text { Pre-test } \\
\text { Knowledge } \\
\text { before } \\
\text { training } \\
\text { (respondents } \\
\text { in \%) }\end{array}$ & $\begin{array}{c}\text { Pre-test } \\
\text { Knowledge } \\
\text { after training } \\
\text { (respondents } \\
\text { in Number ) }\end{array}$ & $\begin{array}{l}\text { Post-test } \\
\text { Knowledge } \\
\text { after training } \\
\text { (respondents } \\
\text { in \%) }\end{array}$ & $\begin{array}{c}\text { Change in } \\
\text { perception } \\
\text { level }(\%)\end{array}$ \\
\hline 1 & $\begin{array}{l}\text { Knowledge of Species } \\
\text { of Mushroom and } \\
\text { Identification of edible } \\
\text { mushroom }\end{array}$ & 15 & 6 & 235 & 94.0 & 88 \\
\hline 2 & $\begin{array}{l}\text { Nutritive and medicinal } \\
\text { value of mushroom }\end{array}$ & 14 & 5.6 & 214 & 85.5 & 80 \\
\hline 3 & $\begin{array}{l}\text { Materials } \\
\text { Techniques used for } \\
\text { different types of } \\
\text { mushroom production }\end{array}$ & 9 & 3.6 & 223 & 89.2 & 85.6 \\
\hline 4 & $\begin{array}{l}\text { Pest and disease } \\
\text { infestation in mushroom }\end{array}$ & 4 & 1.6 & 188 & 75.2 & 73.6 \\
\hline 5 & $\begin{array}{l}\text { Profitability in } \\
\text { mushroom cultivation }\end{array}$ & 54 & 21.6 & 245 & 98.0 & 76.4 \\
\hline 6 & $\begin{array}{l}\text { Harvesting and storage } \\
\text { process }\end{array}$ & 15 & 6.0 & 219 & 87.6 & 81.6 \\
\hline 7 & $\begin{array}{l}\text { Value added products of } \\
\text { mushroom }\end{array}$ & 9 & 3.6 & 215 & 86.0 & 82.4 \\
\hline 8 & $\begin{array}{l}\text { Awareness of loans, } \\
\text { schemes and subsides } \\
\text { provided by public or } \\
\text { private institutions for } \\
\text { establishment of } \\
\text { mushroom production } \\
\text { unit }\end{array}$ & 4 & 1.6 & 235 & 94.0 & 92.4 \\
\hline
\end{tabular}


Table.2 Involvement of trainees in mushroom cultivation from 2016-2019

\begin{tabular}{|l|l|}
\hline Number of trainees & $\mathbf{2 5 0}$ \\
\hline Number of trainees started their mushroom enterprise & 26 \\
\hline Number of trainees dropped out & 08 \\
\hline Number of trainees involved in value addition to mushrooms & 2 \\
\hline Value added products of mushrooms & 2 \\
\hline
\end{tabular}

Table.3 Average production of milky mushrooms by the trainees

\begin{tabular}{|l|c|c|}
\hline Years & $\begin{array}{c}\text { Average production of milky } \\
\text { mushrooms by the trainees (qts.) }\end{array}$ & \begin{tabular}{c} 
Average Income earned (in rupees) \\
\hline $\mathbf{2 0 1 6 - 1 7}$
\end{tabular} $\mathbf{1 8}^{\mathbf{2 0 1 7 - 1 8}}$ \\
\hline $\mathbf{2 0 1 8 - 1 9}$ & 26 & $3,24,000$ \\
\hline
\end{tabular}

Fig.1 Value added milky mushroom pickles

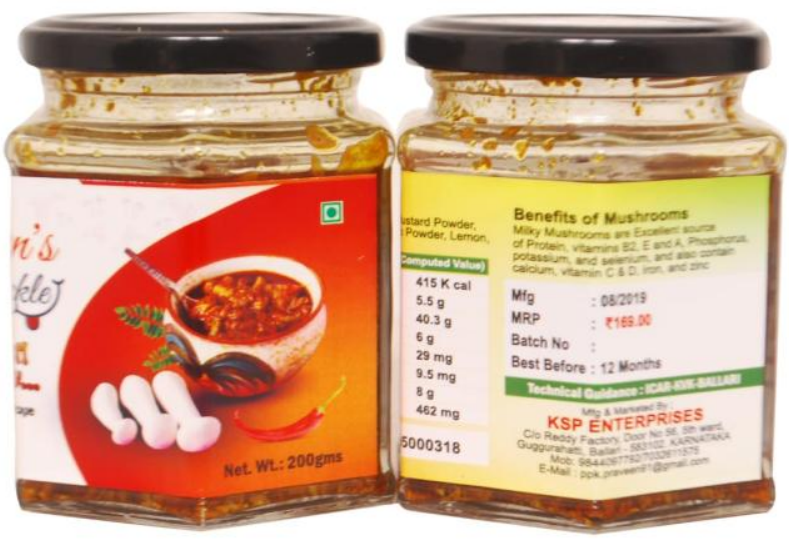

As Mushrooms contains high moisture and are delicate in texture, these cannot be stored for more than 24 hours at the ambient conditions of the tropics. This leads to weight loss, veil opening, browning, liquefaction and microbial spoilage of the product making it unsalable. Effective processing techniques will not only prevent the post-harvest losses but also results in greater remuneration to the growers as well as to the processors (Wakchaure, 2014).

Mushrooms are nutritious, medicinal and functional food. It contains low calories, high protein, dietary fiber, vitamins, and minerals. It is very promising in its agribusiness trend, but has a constraint low shelf life (Jahan, 2019).

The Marketing is not well defined as most of the time the small and marginal farmers are those who cultivate the mushroom and thus get to the final consumer without letting the produce pass through other agents like wholesalers, retailers and processor. This poses the problem of insufficient added value 
to the mushroom sold and lesser job opportunities.

Market survey on availability of mushroom products was done to know the wider use of mushrooms. The result of market survey showed availability of very less number of mushroom products namely pickles, soup mixes and canned mushrooms in the local market. When looked into the available processed mushroom products they were made of either oyster or button mushrooms, no single milky mushroom product was seen in the market. The reason may be lack of consumer awareness on mushroom consumption, lack of local mushroom growers, lack of knowledge on value addition to the mushrooms.

In conclusion, training and demonstration are integral part of KVK extension system. ICAR- KrishiVigyan Kendra's playing an important role in encouraging rural farmers, unemployed youth and farm women to take up simple and quick income generating enterprises from where they can earn additional income. One of the interesting facts is that many unemployed non-agricultural background youth are showing interest in mushroom cultivation. Oyster and button mushrooms are known to many farmers and consumers from long back, whereas milky mushroom cultivation and consumption is a new challenge to the localities of Ballari district. The trainee respondents were inspired greatly by the easy method of mushroom production. The mushrooms were included in their daily diet and supplemented additional nutrition to them. The perception levels of the respondents about mushroom and its production after the training have changed. It also provided an opportunity to strengthen the link between farmers and scientists which helped in technology dissemination and overall development of weaker section. Value addition technologies being demonstrated in the training programmes helped the growers in fetching the additional income. Not withstanding the importance of mushroom as health food and its cultivation as a remunerative agribusiness, it is yet to find desired importance in India. The regular supply of quality spawn is the most important intervention that needs to be addressed for mushroom entrepreneurship to flourish. Hence, there are so many factors for sustaining the mushroom production. Proper training and guidance to the farmers is much essential and would help the interested growers to sustain and earn their livelihood.

\section{References}

Arti. K and Chauhan S.K. 2014., Economic Viability of button mushroom cultivation in Himachal Pradesh, India. J. Agric. Res.., 48 (2) 134-139.

Bhavani, V.B., Anuradha, G., Gopinath, R. and Velan, A.S. 2008.Report of the State of the Food Insecurity in Rural India. M. S. Swaminathan Research Foundation and World Food Progamme, FAO, MSSRF Report-27, pp. 39-42.

ICDS. 1983. Central Technical Committee on Health and Nutrition. All India Institute of Medical Sciences, New Delhi.

Jahan A and Singh B K. 2019., Mushroom Value Chain And Role Of Value Addition., International Journal of Botany and Research (IJBR), Vol. 9, Issue 1, Jun 2019, 5-1.

Kesavan, P.C. 2015. Shaping science as the prime mover of sustainable agriculture for food and nutrition security in an era of environmental degradation and climate change. Current Science 109(3): 488-501.

Michael, A. Gold., Mihaela, M. Cernusca. and Larry, D. Godsey. 2008. A Competitive Market Analysis of the United States Shiitake Mushroom Marketplace. Hortitechnology. 18(3): 489- 499. 
Naveena, K.P., Mouzam, S.M. and Bellundagi, V. 2016. Economic importance and consumer preferences for neglected and underutilized crop species in Karnataka. Economic Affairs 61(1): 135-140.

NFHS-3. 2006. National Family Health Survey-3, 2005-2006. Ministry of Health and Family Welfare, Govt. of India, International Institute for Population Sciences Deonar, Mumbai. Available at http://www.indiahealthstat. com.

Shahi, V., Shahi, B., Kumar, Singh, K.M. and Pooja, K. 2018. Impact study on mushroom cultivation for micro entrepreneurship development and women Empowerment. Journal of Pharmacognosy and Phytochemistry.,
2018; SP4: 01-04.

Sheela, K. 1999. Nutrition scenario in Karnataka, a state in southern India. Asia Pac. J. Clin. Nutr. 8(2): 167-74.

Shirur, M., Shivalingegowda., Chandregowda and Rana, R.K., Singh, J., Chahal, V.P., Rathee, A. and Singh, K. 2015. Economic Empowerment of Scheduled Caste Landless Rural Women through Mushroom Cultivation: A Case Study. Economic Affairs 60(4): 591-594.

Singh, R. and Suresh, R. 2007. Cost-benefit analysis of mushroom cultivation. Indian J. Agric. Res. 41(4): 256-261.

Singh, R. and Suresh, R. 2007. Cost-benefit analysis of mushroom cultivation. Indian J. Agric. Res. 41(4): 256-261.

\section{How to cite this article:}

Shilpa Huchchannanavar, G. Ravishankar and Anandkumar, V. 2020. Impact of Milky Mushroom Cultivation and Value Addition Trainings among the Unemployed Youth of Ballari District. Int.J.Curr.Microbiol.App.Sci. 9(01): 1853-1860. doi: https://doi.org/10.20546/ijcmas.2020.901.207 